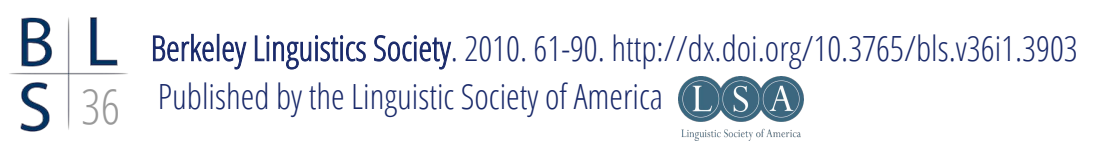

\title{
Writing in the World and Linguistics
}

\author{
PETER T. DANIELS \\ Independent Scholar
}

\section{Introduction}

It seems to me that the study of writing is about where the study of language was before the development of linguistics over the past century-and-a-bit. Everyone we know knows how to write, and therefore everyone we know thinks they know about writing. This paper looks at how writing has been presented to the general public, and how it has been treated in linguistics since the first real textbook of 1933.

I then turn to how writing has been studied by specialists-beginning considerably earlier than modern linguistics - noting the transition from antiquarianism to serious investigation, and then the very gradual incorporation of the study of writing into mainstream linguistics: through tentative articles by general linguists, to a change in attitude in textbooks, to a sudden spate of books on writing by linguists (few if any of whom can be considered specialists).

Finally, I deal with some problems in the treatment of writing by general linguists who all too readily try to apply models of language to questions of writing without taking note of the fundamental distinction between language and writing. These problems include the adaptation of terminology from one field to the other without considering the implications, the assumption that writing change must be just like, or totally unlike, language change, and questions of the relation of writing to language.

\section{$1 \quad$ Popular Treatments of Writing}

\subsection{Maps}

If I were going to make a map to accompany a conventional history of writing, it might look like Figure 1 (Daniels 2007). The numbers 1-17 mark the "alphabets" that are likely to be mentioned (parenthesized items perhaps not so likely), in roughly chronological order, with the three lettered entries perhaps earning a note. 


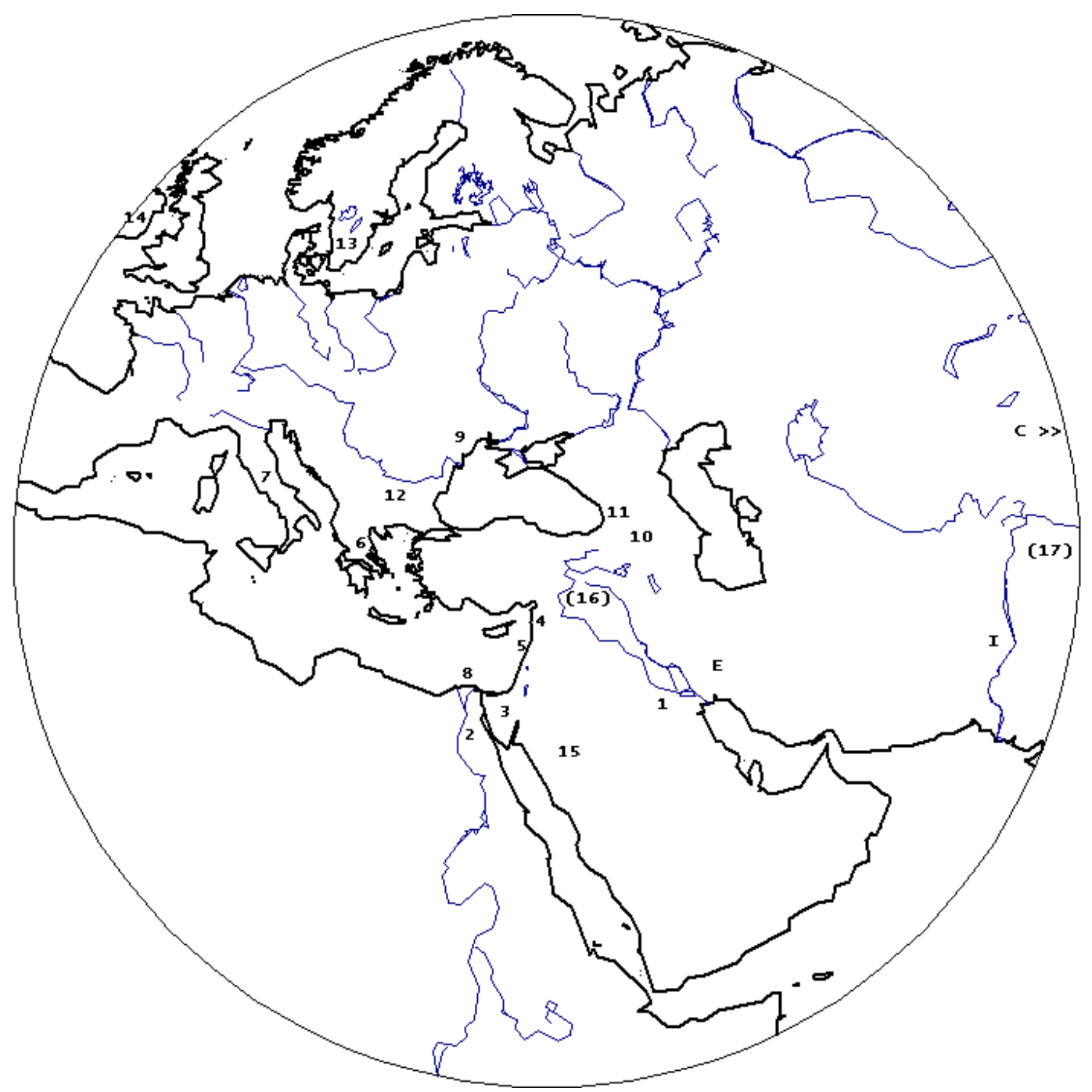

Figure 1. A representation of the "standard" history of writing.

$\begin{array}{lll}\text { 1 Sumerian } & 7 \text { Roman } & 14 \text { Ogham } \\ \text { 2 Egyptian } & 8 \text { Coptic } & 15 \text { Arabic } \\ \text { 3 Proto-Sinaitic } & 9 \text { Gothic } & \text { (16) Syriac } \\ \text { 4 Ugaritic } & 10 \text { Armenian } & \text { (17) Indian } \\ 5 \text { Phoenician (Punic } & \text { 11 Georgian } & \text { E Elamite } \\ \text { Old Hebrew Aramaic } & \text { 12 Slavonic (Glagolitic } & \text { I Indus Valley } \\ \text { Square Hebrew) } & \text { Cyrillic) } & \text { C Chinese } \\ 6 \text { Greek } & \text { 13 Runes } & \end{array}$

The striking dust jacket of the British hardcover edition of Nicholas Ostler's Empires of the Word (2005) http://www.nicholasostler.com/nicholas/books forms a world map with geographical areas as blocks of type in the font of the area. The designer was advised by the author, who selected the content of the passages used as well as the scripts. I thought this was a unique and innovative idea, but it turns out it was anticipated-in 1741. 


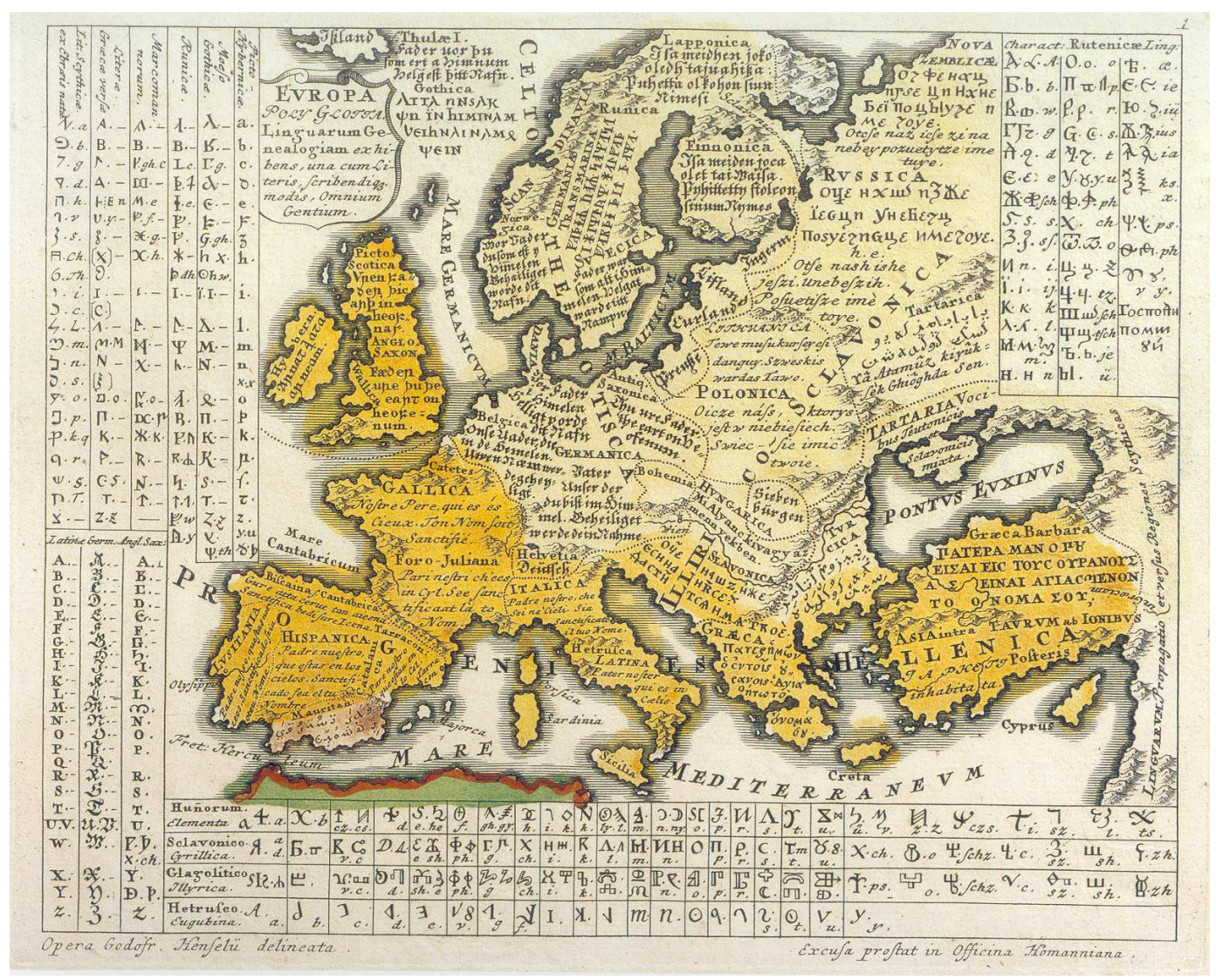

Figure 2. Hensel 1741, map 1.

Figure 2 is one of a set of four maps (those for Africa and the Americas are rather rudimentary!) that purports to present the Lord's Prayer in the local language and script. On the map of Europe, the languages included are Portuguese, Spanish, Catalan, and Basque; French and Occitan; Italian and Latin; Danish, Belgian, German-and "ancient Saxon"; Irish, "Picto-Scotian," and Anglo-Saxon (but no English); to the north and east are several more samples that warrant magnified examination.

In Asia (Figure 3) we find Hebrew, Arabic, and Syriac; Armenian and Georgian; Persian, a rather fanciful "Indo-Brahman," and Tamil ("Malabarica"); unreliable-looking Chinese, and what seem to be pure invention for Uzbek and Japanese. Under "Scythico-Tataric" are displayed "characters previously unknown to us that were exhibited at Strassburg." This got me wondering what sort of representation writing has had in modern atlases. (How languages are depicted in atlases is the topic for a whole other treatment.) The earliest I have found is in the notorious Peters Atlas of 1989 (Peters 1990:116-17), which purported to uniquely represent the true relative areas of all land masses (while unmercifully distorting the shapes of those land masses). The display contains a main world map and five subsidiary ones each occupying one quarter its area; the large one shows direction of writing (left to right, right to left, top to bottom) color-keyed to each nation- 


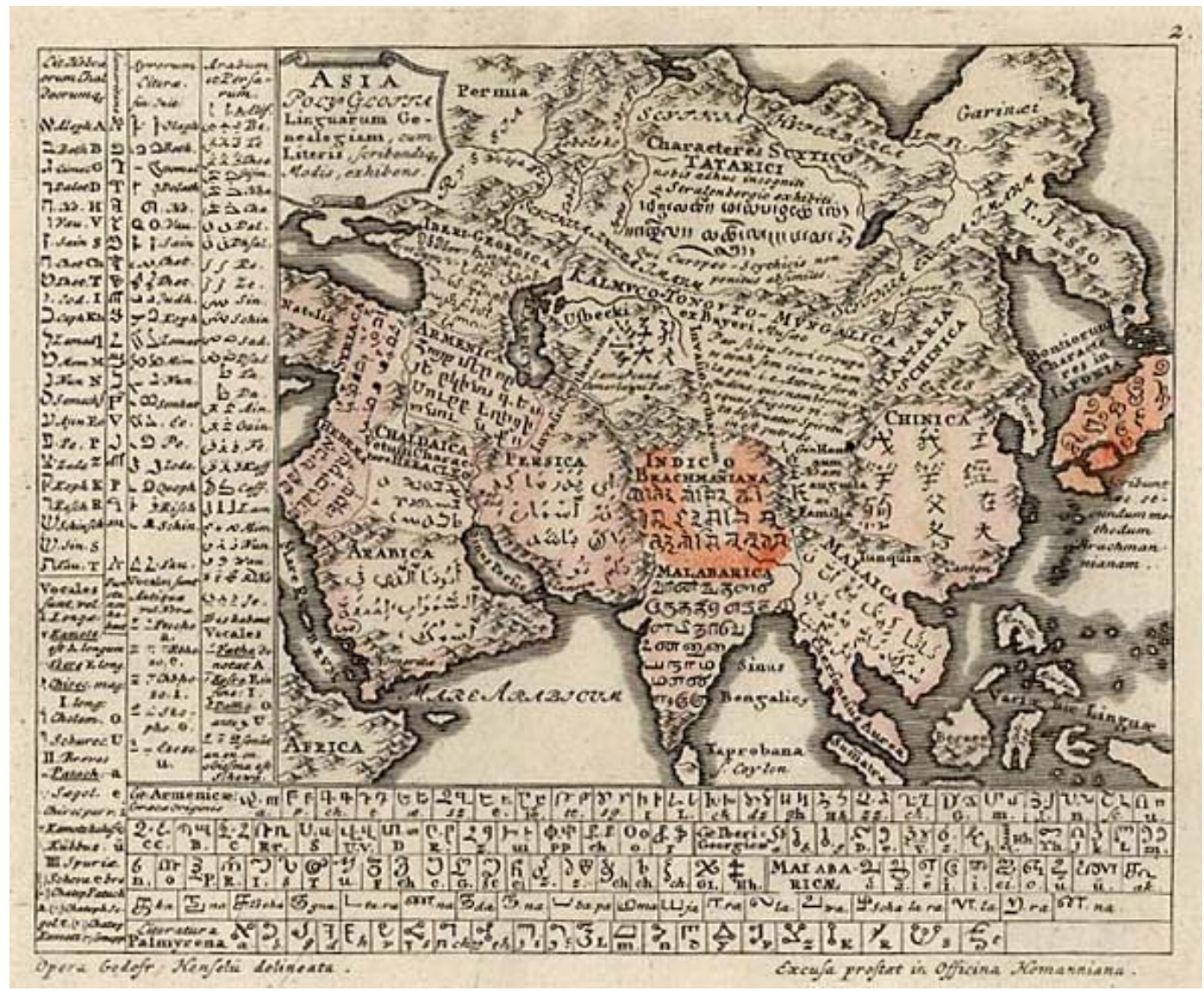

Figure 3. Hensel 1741, map 2.

suggesting that this is the most interesting or the most important thing to note; the five smaller maps show the countries that use scripts whose origin is, respectively, Chinese (there is even a tiny dot for Singapore), Indian, Greek, Latin, and Arabic.

Not until almost twenty years later did maps of writing show up in historical atlases. They do not seem to be found in serious atlases intended for the scholarly community, but they have now appeared in two popular atlases that are widely available as "bargain books" at major bookstore chains in new editions and formats every few years.

Dorling Kindersley's Atlas of World History (Black 2005) combines its treatment of writing with that of numbers and calendars (32). The Old World portion of the map condenses a great deal of information in the form of labeled arrows, shaded geographic areas, and text blocks into a single graphic, including threecharacter samples of a few scripts. There is, moreover, another map, in the Ancient Near East section (223), repeating much of the same information with somewhat thinner arrows.

Its main competitor, also called Atlas of World History, is the latest in a long line (Haywood 2009). Its presentation (§1.07), which is not in the 1997 or 2002 editions, is rather more sophisticated - arrows are replaced by a genealogical tree below, to show more holistic information. The map's shading shows the extent of 
writing at seven periods, $3000 \mathrm{BC}$ to $\mathrm{AD} 1500$. The many more writing samples are placed in tablets of four or five characters; the color-codings of the tablets correspond to those of the tree (which has at least one mistake, branching Mongolian writing off of Tibetan, and curiously it omits Hebrew-though Hebrew is mentioned in the accompanying text). The very presence of Tibetan, Mongolian, and modern Indic scripts is unusual in popular treatments of writing. The text makes two rather questionable assertions: "Elamite and Indus valley pictographs derive from Sumerian pictographs" (sheer speculation) and the Chinese Oracle Bone script "was also used for record-keeping" (this is likely but unevidenced).

\subsection{Trees}

The genealogical tree in fact seems to be a fairly recent device in the study of the history of writing. The earliest comprehensive one I have found (Figure 4) is from my teacher I. J. Gelb's celebrated volume published in 1952 but largely written in the late 1930s. It shows relationships of descent and places their starting points on forty equally spaced rows representing four thousand years of innovations - a chronological nicety that has not often been imitated. I return to this chart later.

David Diringer went from a simple typographic tree in his first edition giving barely more information that the names of the chapters on each group of scripts to a graphic rendition with branches and leaves in his third edition (Diringer 1948:573; 1968, vol. 2: frontispiece).

Figure 5 is surely the apotheosis of the writing family tree (or trees), though chronological precision is sacrificed to comprehensiveness (Kulundžić 1957). The original is about 24 by 17 inches; years ago I photocopied it in eight fragments and pieced them together, and it took six scans to capture the whole thing. The whole left side of the main tree is devoted to South and North Indic scripts.

The treetrunks, from left to right, are as follows: Egyptian, Cretan, PreColumbian, Hittite Hieroglyphs (all with their branches lopped off); Alphabetic Writing; Cuneiform, Easter Island, Mohenjo Daro/Harappan, and Chinese. The vertical scripts are placed in vertical tablets. Some of the branches would be placed differently today - the main tree itself should grow from the Egyptian; Kharoșthi is accorded no connection with Brahmi; deriving Armenian and Georgian from Pehlevi is an older theory (also followed by Diringer and reflected in Gelb's chart, though in the text of the book Gelb discusses only the letternames of those two alphabets); Ugaritic is omitted but perhaps would have been placed (like Old Persian) on the Cuneiform tree according to outer form rather than near the source of the West Semitic branch at the lower right - as might be immediately obvious from the most recent attempt at a genealogical tree (Haarmann 1994: 342), were it not so graphically complex. All the arrows indicating descent and influence are rectilinear and in some places even spiral; there is no hint of chronological information; and Ugaritic is again omitted! In case the diversity within Europe was not set forth clearly enough, further detail is added on the facing page. 


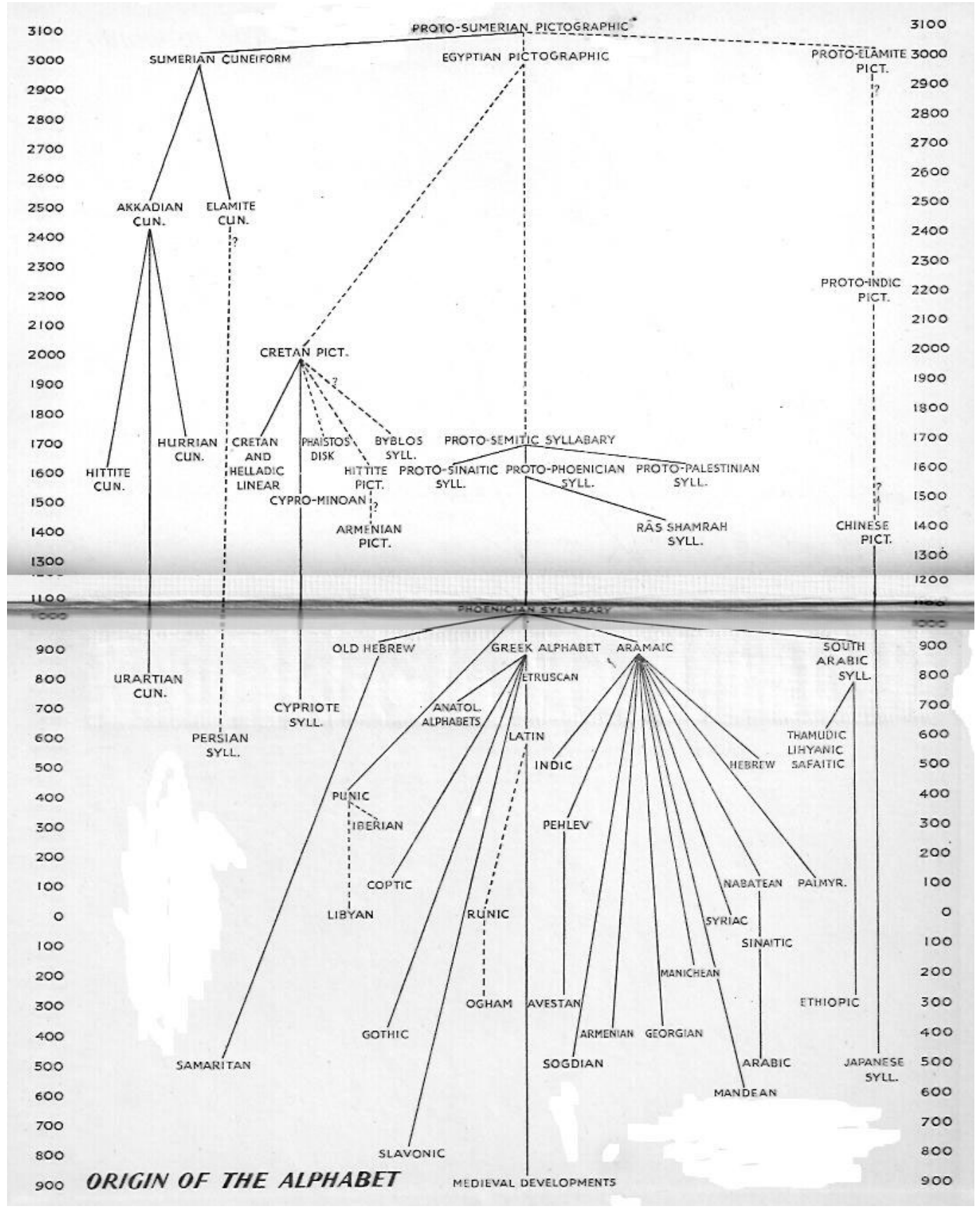

Figure 4. Gelb 1952, endpapers.

\subsection{Popular Books}

Admittedly these script family trees are taken from the scholarly literature. In recent years there has been an explosion of popular books on writing - by journalists, or in coffee table books, or worst, in coffee table books by a journalist. 
Peter T. Daniels

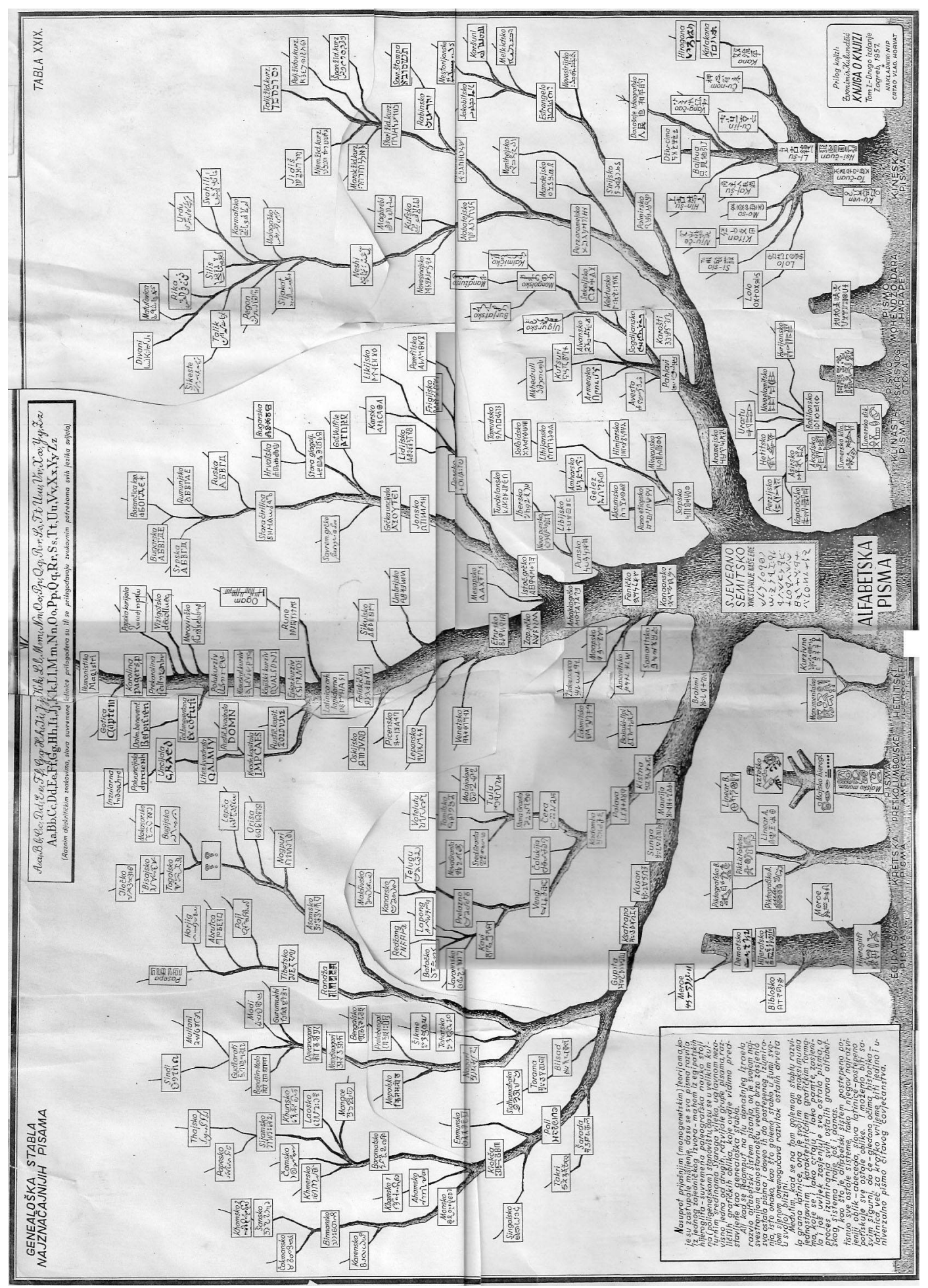

Figure 5. Kulundžić 1957, foldout inside back cover. 


\section{Writing in the World and Linguistics}

My remarks on Jean 1992, Man 2000, Sacks 2003, and others are available on line (Daniels 2000a; 2007:55 n. 2). Sacks's Language Visible was reissued in paperback - and almost immediately, beside it on the shelf was the identical book with a new title, Letter Perfect. The prize for most mistakes per square inch (and some of them are real howlers) goes to Steven Roger Fischer, whose claims to have deciphered both the Phaistos Disk and the Easter Island script have not been validated (Fischer 1999, 2001, 2003). Andrew Robinson is a special case. His Story of Writing (1995) is uninformed from a scholarly point of view and does contain its share of mistakes. But then he researched two small biographies of decipherers, (Robinson 2002b, 2006), and Lost Languages (2002a) is far better. Some ten years ago, in the wake of The World's Writing Systems, I was asked to do a volume in the new "Very Short Introductions" series from Oxford. A few months later, the editor came back and very apologetically reported that "Marketing" had decreed that there was "no market" for a book on writing systems. But now, Andrew Robinson's has just appeared as number 208 (Robinson 2009).

The late Albertine Gaur was Keeper of Indian Manuscripts in the British Museum (and then the British Library), and her volumes are illustrated almost entirely with items from that collection (Gaur 1992, 1994). She is of course impeccably reliable within her field, but not so much so in other areas. She makes the curious claim that there was no calligraphy in India-taking, of course, a sociocultural view of the term (Gaur 2000:126) — but it is clear from many specimens illustrated in books like Losty 1982 that Indian artists and scribes were as concerned with beautiful writing as were artists and scribes anywhere else.

Christin's massive volume (Christin 2002) is not a comprehensive history, but many of its chapters treat unusual topics; but it suffers from atrocious translating. The French original is very useful (as well as beautiful), but the English version can be in many places misleading.

Fortunately, there is now a pretty good book for the general public (Gnanadesikan 2009). Unfortunately it is published by an academic publisher, so it won't get the distribution or marketing it deserves.

\subsection{Encyclopedias}

Midway between popular and scholarly treatments of writing systems are major encyclopedia articles, and I can point to only two or three that merit study. First is "Writing" by Peter Giles, in 29 long columns of the 1902 Tenth Edition of the Encyclopoedia Britannica (a ten-volume supplement to the peerless Ninth, Giles 1903). It contains only two tables - and the first one shows some of the most ob-

scure scripts known: Carian, Lycian, Iberian, and Berber. The second table shows the principal scripts mentioned in the text: Brahmi, Kharoșthi, Oldest Æthiopic, Sabæan, Naskhi (Arabic), Tema 500 BC, Sindjirli 800 BC, Moabite Stone, Phooenician (Cyprus), Greek Inscrip. of Thera, Oldest Latin Forum Inscription. The celebrated Eleventh Britannica of 1911 often contains abridgments of articles from the Ninth and Tenth, and that is the case here: "Writing" was split into "Al- 
Peter T. Daniels

phabet" and the unsigned "Writing" (Giles 1910, 1911; Daniels 2005). To the table it added Cyrillic and Glagolitic. Our topic did not fare so well in the 14th edition, which was continually updated from 1929 to 1973. I have not seen the 1929 original, but from 1930 at least, the pedestrian article "Alphabet" (Atkinson 1930ff.) made no reference to the reprinted accompanying table to which an uncomprehending editor must have added the caption "the presumed development of the modern European alphabet from the Brahmi letters of India"-and dropped the label "Kharoșthi" from the second column. The article was condensed in the early 1960s by Joshua Whatmough, and persisted until 1973 (Atkinson and Whatmough 1961?ff.).

Theoretical articles by I. J. Gelb began to appear about 1960, and in the 15 th edition of 1974, they were gathered under "Writing, Forms of" along with a new review of "Alphabet" history by David Diringer (who did not live to see its publication), in the last and first volumes respectively (Gelb 1973ff., Diringer 1973ff.). There is also a surprisingly extensive and generously illustrated article on "Calligraphy" by many authors (Nash, et al. 1973ff.); the articles "Paleography" (Urry 1973ff.) and the long one on "Epigraphy" (Puhvel 1973ff.) are not illustrated. In 1985 the Britannica was reorganized and the three writing articles along with others were gathered under "Writing." In 1988 Gelb's portion was replaced, and Diringer's portion was lightly edited, by David Olson. The treatment of Indian calligraphy by Donald M. Anderson is simply dropped, as is "Ancient Epigraphic Remains" (Mittelberger 1973ff.). "Epigraphy" and "Paleography" are included in "History, the Study of," and that is where the Britannica stands today. (The DVD version cannot be used for these topics, because most of the illustrations and the script tables accompanying many of the "Languages of the World" articles have not been included, at least as of the 2009 edition.)

The other highly commendable encyclopedia article is "Alphabet" that first appeared in Collier's in 1966 and was carried until the work ceased publication in the late 1990s. It is a full 19 pages, and it's by my phonology professor at Cornell, James Gair. (Gair 1966ff.) Gair is a specialist in Indo-Aryan, specifically Sinhala, and that major branch of writing systems is not neglected here. This article is accompanied by another 7 pages on "Pictographs and Ideograms," by Elizabeth Bowman, who coincidentally had held my job at the Assyrian Dictionary of the Oriental Institute, University of Chicago, in the 1950s (Bowman 1966ff.). I myself have contributed seriously abbreviated articles on "Alphabet," "Writing Systems," and the 26 letters of the English alphabet to the junior high school-oriented World Book Encyclopedia

\section{$2 \quad$ Books by Specialists}

\subsection{Pre-Modern Books}

At this point we should pause to review the sources of information the encyclopedia-writers could draw on (most of the volumes mentioned in $\S 2.1$ can be consult- 


\section{Writing in the World and Linguistics}

ed through books.google.com). Hensel's maps have script tables around the edges: Europe (Figure 2), upper left, (litteræ) Scythicæ, Græcæ, Marcomannorum, Runicæ, Mæsogothicæ, Pictohibernicæ; lower left, Latinæ, Germ., Angl.-Sax.; upper right, Rutenicæ; bottom, Hunorum, Sclavonico-cyrillica, Glagoliticoillyrica, Hetrusco-eugibina; Asia (Figure 3), left, (litteræ) Hebræorum, Syrorum, Arabum et Persorum; bottom, Armenicæ, Iberi-Georgicæ, Malabarica, Palmyrena-we do not know the sources of his information, but they are fairly accurate. Except for "Palmyrena": that script would not be deciphered until 13 years later.

(The first edition of the Britannica in 1768 punted: under "Alphabet" in volume 1 are merely cross references to "Language" and to "Characters," and in a different sense to "Decyphering"; volume 2 carries long essays on GRAMMAR and LANGUAGE with no mention of alphabets, and displays of CHARACTERS used in such fields as astronomy and chemistry, but nothing on letters; and there is no entry for "Decyphering" at all.)

The Encyclopédie, on the other hand, published in the second volume of plates no less than 25 plates of scripts from throughout Eurasia-including several Indian scripts, Tibetan, Manchu, the 214 Chinese radicals (with explanations), and even three varieties of Japanese kana (Caracteres et alphabets 1763).

In England, the antiquarian Thomas Astle (1784) collected many examples of Latin and English paleography; he includes only one display of non-roman alphabets. He refers the reader to the Encyclopédie for "many other oriental alphabets."

Responsibility for this sort of information shifted to printers around the turn of the 19th century. Greek and Hebrew were available as a matter of course at 18thcentury printers'. William Caslon in 1785 offered two sizes of Syriac and one of Arabic, along with Armenian, Samaritan, Gothic, Coptic, Æthiopic, Etruscan, and four sizes of Saxon. The Syriac sample is the Lord's Prayer, but words are illicitly divided between lines; Giambattista Bodoni sets the same text a few years later, with accuracy. Bodoni also showed Turkish, Tartar, Persian, Armenian, Palmyrene, Servian, Illyrian, Gothic, Tibetan, Georgian, Brahmin, Malabar, German, and Russian (and those are only the selected pages that have been placed on the website for de Jong, Purvis and Tholenaar 2009-10).

In 1824, the English printer John Johnson created the two exquisite, tiny volumes of Typographia, including more than 200 pages devoted to the history and variety of writing (2:260-480, encompassing what may have been the first account in English of Champollion's decipherment of the Egyptian hieroglyphs, 334-48). The page on the niceties of Syriac (317) is quite accurate. Many of his prose descriptions are taken directly from the commentaries on the Encyclopédie's plates. A number of pages show large letters set vertically used the type (apparently carved in wood) created for Edmund Fry's Pantographia (1799), which was widely cited but carried quite a few fanciful entries; though the Mandaic (after the Encyclopédie) is accurate (284, cf. Johnson 1824, 2:318).

The founding document of Semitic epigraphy is Ulrich Friedrich Kopp's Bilder und Schriften der Vorzeit 'Images and scripts of the past' (Kopp 1819-21). This work also discusses Germanic antiquities and even a bit of Chinese, but the 


\section{Peter T. Daniels}

bulk of volume 2 is devoted to Semitic alphabets. It includes a series of dated Phoenician coin legends arranged chronologically (pl. opp. 212), the development of Phoenician letters (215-18), and summary charts of all the known Semitic scripts as well as two from India (377-98).

The earliest work on writing that could be considered theoretical was by Peter Stephen Duponceau, a Frenchman who came to this country in 1777 as secretary to Baron von Steuben because of his fluent English and German, became a lawyer, and became a pioneer in studying Native American languages (Smith 1983, Robins 1987). His Dissertation on the Nature and Character of the Chinese System of Writing (1838) seems to have been completely overlooked in its time. It was published in January 1838 - but in Philadelphia. The importance of the work is this (Daniels 2009b): It seems to be the very first place that the tripartite typology of writing systems was enunciated. Writing systems could be based on the segment, the syllable, or the word (what we now would call the morpheme).

\footnotetext{
The elements of language are words, syllables, and the simple sounds represented by the letters of our alphabets. Those three elements are all produced by the vocal organs; and, as all writing is made to be read by all who understand the language to which it belongs, and to be read aloud as well as mentally by all in the same words, and in the same order of words, it seems clear that the written signs must represent or recall to the mind some one or other of those three elements; and hence we have three graphic systems, distinct from each other, but formed on the same general principle - the elementary or alphabetic, the characters of which, called letters, represent singly the primary elements of speech, which are simple sounds; the syllabic, that represents syllables which, for the most part, have no sense or meaning, but only serve as elements in the composition of polysyllabic words; and lastly, the lexigraphic, which by means of simple or combined signs, represent the words of a language in their entirety; and this last mode seems to be more particularly applicable to monosyllabic languages, in which every syllable has a sense or meaning connected with it, which supplies a method for the formation of the characters, the multiplicity of which otherwise might create confusion. (Du Ponceau 1838:xxiii [here and below, underlining emphasis added])
}

Duponceau also recognized the fact that Chinese characters are not "ideograms," a sort of what has been called a "universal character" (Eco 1995), but that each one stands for a word (that is, a morpheme); and not only for its meaning, but its sound as well. But the work seems to have had no effect at all, until it was discovered by Berkeley's own Chao Yuen Ren more than a century later (Chao 1940).

Let us pause in the middle of the nineteenth century. Maximilian Schele de Vere of the University of Virginia, who would later become a pioneering investigator of Americanisms, dedicated the last 54 pages of Outlines of Comparative Philology to a "Brief History of the Art of Writing" (1853). Curiously, his reports on cuneiform writing (then just in the process of decipherment) and Egyptian are considerably more up to date and accurate than are his remarks quoted here and his pages on the Greek alphabet and its descendants:

The history of written language, so far as its outward form is concerned, is not unlike that of spoken language: it proceeds, like the latter, from the most complicated to the most simple. (383) 


\section{Writing in the World and Linguistics}

Of all the Eastern modes of writing, the Sanscrit is, of course, the most important, because, like the idiom it represents, it presents to us the original form from which the Greek and Roman, the Germanic and Slavonic, are derived. (401)

The finest collection ever of exotic type specimens was assembled by the printer and shorthand theorist Karl Faulmann in 1878 for the Austro-Hungarian Imperial and Royal printing house (1880a). It has remained in print ever since. $\mathrm{He}$ put his magnificent collection of types into action in an "illustrated history of writing" (1880b); unfortunately he was no scholar, and he repeated the most fanciful assertions about the history of writing. Here (420) he relates the shape of Arabic $h$ directly to Syriac $s$, three different Egyptian hieroglyphs, and Syriac $g$.

$\rightarrow h$ ist das syrische $s s$, das ägyptische $n$ (Hintertheil), in der Mitte ist es als \& der Muskel, ägyptiseh $\rightarrow$, auch die singuläre Form von $\Rightarrow g g f o$ (Kraut), daneben tritt $\checkmark$, das syrische $g$, als $h$ auf, am Ende ist es wieder das Hintertheil.

A pendant to this genre is the Notices sur les caractères étrangères edited by the Assyriologist Charles Fossey (1927) on the occasion of the 17th International Congress of Orientalists in Oxford in 1928, greatly expanded for the 21st Congress in Paris in 1948. It displays the fonts available at the Imprimerie Nationale with brief descriptions by a host of French specialists. Similar, though smaller in compass and with unsigned descriptions, is the type catalogue issued by the Government Printing Office in Berlin (Bundesdruckerei 1969).

\subsection{Scientific Books}

Fortunately, just three years later, the first scientific book on writing made its appearance, in two volumes subtitled "Semitic Alphabets" and "Aryan Alphabets"-where the latter simply means 'Indo-European' (Taylor 1899; Daniels 2002). This work was the standard reference on writing systems for more than half a century. Indeed the statement by Edward Clodd, in The Story of the Alphabet (1900:5), is typical: “Canon Isaac Taylor's 'History of the Alphabet' is necessarily charged with a mass of technical detail which is stiff reading even for the student of graphiology"; and, regarding the scripts of India, "those who care to pursue a subject yielding to few in dryness will find it summarized in the tenth chapter" of Taylor's work.

But Taylor is important not only as a source of data and careful discussion of hypotheses about the descent and spread of writing systems. He also, apparently independent of Duponceau, became the first scholar of influence to use the tripartite typology of writing systems that would be repeated for more than a hundred years:

1) Verbal signs, which stand for entire words;

2) Syllabic signs, which stand for the articulations of which words are composed;

3) Alphabetic signs, or letters, which represent the elementary sounds into which the syllable can be resolved. (Taylor 1899, 1:6) 


\section{Peter T. Daniels}

And he embraces the notion of evolution, explicitly invoking Darwin, noting

It is owing chiefly to the discovery and application of modern principles and methods that Epigraphy and Palæography can claim to be reckoned among the exact Sciences.... Of these principles the most important is the doctrine of Evolution. ... Discarding the obsolete notion of arbitrary invention or creation, we seek for self-acting causes adequate to produce the results which are detected by minute research. ... Slow differentiation by minute variations ... proves historically to have been the method by which the transformations of alphabets, as well as of languages, of animals, of plants, and even of the surface of the globe itself, has been effected. (2:363)

After World War II there was a spate of single-author volumes comprising historical surveys of the world's writing systems. David Diringer's (1948) is the best known, James-Germain Février's (1959) is the one whose evaluations I find most judicious, Marcel Cohen's (1958) is the most ambitious, Johannes Friedrich's (1966) is the most concise, and Hans Jensen's (1969) has the fullest bibliography to date. I can't honestly recommend the two most recent (Haarmann 1990; Coulmas 1996).

\subsection{Linguistics Textbooks}

The field of descriptive linguistics can be said to have begun after Taylor's time. The discovery that unwritten languages, in Africa particularly, and then in North America, were amenable to the same analytic techniques as the familiar languages led early linguists to realize that, as Ferdinand de Saussure put it, writing exists for the sole purpose of representing language - though his two translators have rendered the statement rather differently:

Language and writing are two distinct systems of signs; the second exists for the sole purpose of representing the first. The linguistic object is not both the written and the spoken forms of words; the spoken forms alone constitute the object. (Saussure 1959:23)

A language and its written form constitute two separate systems of signs. The sole reason for the existence of the latter is to represent the former. The object of study in linguistics is not a combination of the written word and the spoken word. The spoken word alone constitutes that object. (Saussure 1983:24)

In An Introduction to the Study of Language (1914), Leonard Bloomfield's only concern with writing was to note that standard orthography is not adequate for the study of language, and a phonetic alphabet is needed. But by the time of his canonical Language (1933), he had adopted Saussure's position: "Writing is not language, but merely a way of recording language by means of visible marks" (21); "For the linguist, writing is, except for certain matters of detail, merely an external device, like the use of the phonograph" (282).

The textbook for my introductory linguistics class, in 1969, agrees but with some nuance:

A written language is typically a reflection, independent in only limited ways, of 


\title{
Writing in the World and Linguistics
}

spoken language. As a picture of actual speech, it is inevitably imperfect and incomplete. ... Linguistics must start with thorough investigation of spoken language before it proceeds to study written language. (Gleason 1961:10f.)

Gleason seems to leave room for the investigation of written language as a different object from spoken language.

\begin{abstract}
Written communication must be sharply distinguished from spoken. The common tendency to use "language" to refer to either indiscriminately has so frequently given rise to serious confusion, not merely among lay people, but also among professional linguists, that many are reluctant to use it of any written code at all, even with explicit qualification. Many linguists consider all forms of writing entirely outside the domain of linguistics and would restrict the discipline to the consideration of spoken language only. (408)
\end{abstract}

Bloomfield's most devoted disciple does not envision written language as a field of study:

Though writing is not the linguist's primary concern, he is interested in it, as any educated member of our society of course is .... Writing is itself of tremendous importance in human life, and the nature and history of writing can only be clearly understood in terms of the workings of language. (Hockett 1958:539).

The most orthodox and most ardent American Descriptivist uncompromisingly sets forth the Saussurean view:

Once we have made the effort required to turn our attitude right side out, and realize that, in language, speech is fundamental and writing (despite its undeniable importance in modern life) only a secondary derivative and representation of speech, then whole new vistas are opened up to us. (Hall 1964:9)

The function of writing is to give a partial representation of speech. For native speakers of a language, the purpose of a writing system is simply mnemonic, to call to mind something that they already know. (33)

\subsection{Linguistic Studies of Writing}

Hall, though, was one of several American Descriptivist linguists who turned their attention to the study of writing systems (Hall $1960=1963$ ). Hall attempted to apply emic theory to writing systems - but this approach is doomed, because phonemes, morphemes, and the rest relate to subconscious mental structures, the organization of nonsignificantly varying smaller units into significant units, whereas writing systems are necessarily created consciously and need not and do not follow emic principles (Daniels 1991). (There is also the question of what would count as a grapheme in any particular language - are small a and capital A two graphemes, or is there a grapheme of capitalization? Is each Chinese character a grapheme, or the components it is compounded from, or even the individual brush strokes?)

The Voegelins (Voegelin and Voegelin 1961), Hill (1967), and Herrick (1974) 
are among those in this school who essayed studies of the typology of writing. Bolinger (1946) and Berkeley's own Malkiel (1968) contributed articles on uses of writing that go beyond the simple representation of language.

The only current linguistics textbooks I have access to are those available on amazon.com with the "look inside" feature. One has a clear statement of the nature of written language, different from anything seen in the textbooks of my time: "The language used in writing typically differs from the language used in speaking, reflecting and communicating the different conditions under which language is produced and its various purposes" (Fasold and Connor-Linton 2006:17)

Although the assertion "many cultures" is incorrect, the page excerpted here summarizes the understanding of script origins due to me, presented below:

Segment-sized units have a far less important role in poetry or writing systems than do, say, syllables .... It might seem bizarre to say that the segment plays little role in writing systems, since very many languages have alphabetic writing systems and such systems are clearly based on segments. However, ... a phoneme-based writing system seems to have been 'invented' (or rather, gradually evolved) just once in the history of human literacy. Now, many cultures have evolved their own writing systems independently, and, in all other cases, they are based either on pictures representing whole words ... or on the syllable. (Radford, et al. 2009:119)

But between Gelb's Study of Writing of 1952 (lightly augmented reissue in 1963) and his death 33 years later, there were no books devoted to the theory of writing. Geoffrey Sampson (1985) was first into the lists, then John DeFrancis (1989); and there have been three textbooks - two by Florian Coulmas (factually unreliable: (Coulmas 1989, 2005; Daniels 2006b), and one by Henry Rogers (2005).

And the 1990s saw three encyclopedic works - two corporate, and one by a single author (Coulmas 1996). The scope of the German work (some of the content is in English) is wider than is usually seen in writing books (Günther and Ludwig 1994-96). It treats a limited number of scripts from a variety of viewpoints, including literacy and education. The World's Writing Systems (Daniels and Bright 1996) is devoted mainly to orthography, supplemented with historical information as needed. Nakanishi's slim volume (1980) remains a useful survey of scripts currently in use, with many historical notes. I have made even smaller surveys, in the Blackwell Handbook of Linguistics (with tables) and the Cambridge Handbook of Literacy (without tables) (Daniels 2001, 2009a).

\section{Theory of Writing}

But to come back to a general linguistics textbook, Edward Finegan is well known for his study of written versus spoken language, so it is no surprise that his textbook includes a subchapter on that topic; but the history of writing that precedes it contains (at least in the first edition) several incautious statements, embracing a monogenesis, stimulus-diffusion model; an absurdly wide timeframe for the in- 
vention of cuneiform writing; and a counterintuitive "Middle Eastern syllabary" notion:

To use a written symbol to represent a sound is a great achievement .... To use one symbol to represent another, as writing does, required a staggering leap of the imagination. (Finegan and Besnier 1989:359)

For all that is known, it was probably made only once in human history. ... [It] took place [in] Mesopotamia sometime between 3500 and 2600 B.C. (359f.)

The first alphabet was developed by the ancient Greeks from a Middle Eastern syllabic system that they had borrowed around 800 B.C. (372)

Where did this come from? It came from Gelb. He continues to use Taylor's tripartite typology:

\begin{tabular}{|c|c|c|c|c|}
\hline 1. Word-Syllabic: & $\begin{array}{l}\text { Sumerian } \\
\text { (Akkadian) }\end{array}$ & Egyptian & $\begin{array}{l}\text { Hittite } \\
\text { (Aegean) }\end{array}$ & Chinese \\
\hline 2. Syllabic: & $\begin{array}{l}\text { Elamite } \\
\text { Hurrian } \\
\text { etc. }\end{array}$ & $\begin{array}{l}\text { West Semitic } \\
\text { (Phoenician) } \\
\text { (Hebrew) } \\
\text { (Aramaic) } \\
\text { etc. }\end{array}$ & $\begin{array}{l}\text { Cypriote } \\
\text { Phaistos? } \\
\text { Byblos? }\end{array}$ & Japanese \\
\hline 3. Alphabetic: & & $\begin{array}{l}\text { Greek } \\
\text { Aramaic (voc } \\
\text { Hebrew (voca } \\
\text { Latin } \\
\text { Indic } \\
\text { etc. }\end{array}$ & ed) & 1952:191) \\
\hline
\end{tabular}

But he takes the typology to represent teleology_-just as the inventors of the isolating/agglutinating/inflecting typology took it to represent language evolution and "improvement" - and sets up the "Principle of Unidirectional Development": "Writing ... must pass through the stages of logography, syllabography, and alphabetography in this, and no other, order" (1952:201). The Latin tag Natura non facit saltus 'nature does not make leaps', after Leibnitz, was also quoted by Taylor. The teleological view is even symbolized in the genealogical chart (Figure 4) - where the line from Proto-Sumerian Pictographic through Egyptian, ProtoSemitic, Proto-Phoenician, Phoenician, Greek, Etruscan, Latin, Medieval Developments is a straight line right down the middle, with all other scripts as sidebranches.

But, in order to make the Principle of Unidirectional Development work, Gelb has to assign the West Semitic alphabetic scripts to the "syllabic" category, and the Indic syllabic scripts to the "alphabetic" category-because he well knew that West Semitic developed out of Egyptian and Indic developed out of West Semitic.

Before Gelb, "alphabet" referred to two rather different kinds of script - those that notate only consonants, and those that denote both consonants and vowels. Thus here we have a passage in the Square Hebrew "alphabet" (it happens to be in 


\section{Peter T. Daniels}

Biblical Aramaic) and its translation into English. But Gelb insists that the Hebrew script is a "syllabary with indeterminate vowel."

\section{בה-שעתה נפקו אצבען די יד-אנש וכתבן לקבל נברשתא על-גירא די-כתל היכלא די מלכא

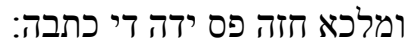 \\ bh-š th npqw 'ṣb 'n dy yd-'nš wktbn lqbl nbršt' 'l-gyr' dy-ktl hykl' dy mlk' wmlk' hzh ps $y d h d y k t b h$. \\ In the same hour came forth fingers of a man's hand, and wrote over against the candle- stick upon the plaster of the wall of the king's palace: and the king saw the part of the hand that wrote. (Daniel 5:5)}

Before Gelb, "syllabary" referred to two rather different kinds of script. In Japanese and Cherokee $(<\mathrm{v}>=[\tilde{\partial}])$, the consonant-vowel symbols are entirely arbitrary: there is no resemblance across vowel rows, or within consonant columns.

\begin{tabular}{|c|c|c|c|c|c|}
\hline Japanese (hiragana) & \multicolumn{5}{|l|}{ Cherokee } \\
\hline あ $a$ い $i \quad う u$ え $e$ お $o$ & $\mathrm{D} a$ & $\mathrm{R} e$ & $\mathrm{~T} i$ & $\mathrm{O} u$ & $\mathbf{i} v$ \\
\hline くkuけkeこko & S $g a, \oslash k a$ & r $g e$ & y gi & A $g o \quad \mathrm{~J} g u$ & $\mathrm{E} g v$ \\
\hline さ $s a し s h i す s u$ せ $s e$ そ $s o$ & od ha & $\mathbf{P}$ he & $\Theta h i$ & $\Gamma h u$ & b hv \\
\hline た ta ち chiつtsuて te と to & W la & $\delta l e$ & $\mathrm{P} l i$ & $\mathbf{M} l u$ & १ $l v$ \\
\hline な $n a に n i ぬ n u$ ね $n e$ の no & $\delta^{h} m a$ & o me & $\mathrm{H} m i$ & У то У & \\
\hline は haひhi ふ fuへhe ほ ho & $\Theta n a, \mathrm{t} h n a, \mathrm{G} n a l$ & h $\Omega$ ne & h $n i$ & $\mathrm{Z}$ no $\mathrm{q} n u$ & $00 n v$ \\
\hline ま $m a$ み $m i$ む $m u$ め $m e も m o$ & $\mathrm{~T} q u a$ & $\omega$ que & $\mathscr{O} q u i$ & $v^{\circ}$ quo $(\mathrm{O} q u$ & ¿Equv \\
\hline ゆ $y u$ & $\mathrm{oO} s, \mathrm{U} s a$ & $4 \mathrm{se}$ & $\mathbf{b} s i$ & $\Phi$ so & $\mathrm{R} s v$ \\
\hline ら raり ri るru れ re ろ ro & $\mathbf{L} d a, \mathbf{W} t a$ & $\mathrm{~S} d e, \mathrm{~T}$ & te $\mathbb{I} d i, \boldsymbol{I}$ & $i \Lambda d o \quad \mathrm{~S} d u$ & $\sigma^{\circ} d v$ \\
\hline わ $w a$ & $\&$ dla, Z tla & L tle & $\mathrm{C} t l i$ & \& tlo $\quad \mathcal{O}$ tlu & $\mathrm{P} t l v$ \\
\hline$h-n$ & $G$ tsa & V tse & $\mathbf{h} t s i$ & $\mathrm{~K}$ tso $\mathbf{d} t s u$ & $C_{m}^{\prime \prime} t s v$ \\
\hline & G wa & $\Longleftrightarrow w$ we & (2) wi & అ wo 9 wu & $6 w v$ \\
\hline & $\infty y a$ & $\beta y e$ & S $y i$ & $\mathrm{~h} y o \quad \mathrm{G}^{\mathrm{w}} y u$ & B $y v$ \\
\hline
\end{tabular}

In Indic scripts and Ethiopic, the consonant plus /a/ is the base form of the letter, and the vowels other than /a/ are shown by additions to or modifications of the letter. Each symbol denotes a CV syllable.

\begin{tabular}{|c|c|c|c|c|c|c|c|}
\hline \multicolumn{8}{|c|}{ Devanagari (Sanskrit) } \\
\hline प $p a$ & पा $p \bar{a}$ & पि $p i$ & पी $p \bar{\imath}$ & पु $p u$ & पू $p \bar{u}$ & प् $p \#$ & प्र $p t a$ \\
\hline त $t a$ & ता $t \bar{a}$ & ति $t i$ & ती $t \bar{l}$ & तु $t u$ & तू $t \bar{u}$ & त् $t \#$ & त्प tpa \\
\hline \multicolumn{8}{|c|}{ Ethiopic } \\
\hline$\cap b \ddot{a}$ & $n \cdot b u$ & ก. $b i$ & $\eta b a$ & n be & $\cap b l, b$ & n bo & $\overbrace{}^{\prime}{ }^{\prime} b^{\prime} \ddot{a}$ \\
\hline$h^{\prime} \prime \ddot{a}$ & k' $u$ & h' $i$ & $h^{\prime} a$ & 'b e & $n^{\prime} \prime l,{ }^{\prime}$ & $\lambda^{\prime} O$ & 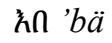 \\
\hline
\end{tabular}


But since these scripts are clearly descended from forms of the Aramaic alphabet, Gelb could not call them syllabaries-because he insisted that the alphabet is the apotheosis of scriptal evolution. He therefore relabeled this type as "alphabets" where the consonants and vowels have systematically different representationsor, "difficult problems" (186).

We can now revisit Gelb's tree (Figure 4) once again, and read what the labels down the center actually say: Proto-Sumerian pictographic, Egyptian pictographic, Proto-Semitic syllabary, Proto-Phoenician syllabary, Phoenician syllabary, Greek alphabet, Etruscan, Latin, Medieval developments. Indic and Ethiopic branch off "Aramaic" and "South Arabic syllabary" respectively, but they are not labeled as either "syllabary" or "alphabet." Neither are any of the other offshoots of Aramaic, where Avestan, Armenian, and Georgian are alphabets in Gelb's terms, and the others are his "syllabaries."

How do I deal with these counterintuitive typological labels (Daniels 2000b)? The beginning of the answer came when I realized that even though the Cherokee and Cree writing systems have always been treated together because they are considered syllabaries with similar user-communities, typologically they are quite different. Cherokee, as we have seen, is a pure syllabary. But Cree Syllabics is systematic: the four signs for each consonant row are rotations or reflections of each other; the specific rotations and reflections are consistent through each vowel column.

\begin{tabular}{|c|c|c|c|}
\hline \multicolumn{4}{|l|}{ Cree } \\
\hline$\triangleleft a$ & $\nabla e$ & $\Delta i$ & $\triangleright_{o}$ \\
\hline$<p a$ & $\vee p e$ & $\wedge p i$ & $>p o$ \\
\hline$C_{t a}$ & $\cup$ te & $\cap t i$ & $\supset$ to \\
\hline b $k a$ & १ ke & $P_{k i}$ & $\mathrm{~d} k o$ \\
\hline し cha & ר che & $\Gamma$ chi & J cho \\
\hline L $m a$ & $\neg$ me & $\Gamma m i$ & \lrcorner $m o$ \\
\hline$\bigcirc n a$ & ○ ne & $\sigma n i$ & $n o$ مـ \\
\hline 々 $s a$ & Y se & ${ }_{s i}$ & † so \\
\hline ל $y a$ & $4 y e$ & 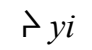 & $\checkmark y o$ \\
\hline
\end{tabular}

And this difference reflects the very different creators of the two systems. Cherokee writing was devised by Sequoyah about 1821, who observed the Americans around him communicating by marks on paper; and he wanted the same thing for his language and people. What he eventually devised was a CV syllabary. Cree syllabics, on the other hand, was devised by a missionary in the 1840s who was familiar with Isaac Pitman's phonetically based shorthand, and arranged his symbols accordingly.

Moreover, whenever someone has invented a script out of nothing-only being aware that other people had this thing called writing - the result is a nonsystematic syllabary (Schmidt 1980). When someone versed in phonetics or phi- 
lology invents a script, the result usually displays phonetic awareness.

So after we recognize more than one type of "syllabary," we are licensed to recognize more than one type of "alphabet," and the counterintuitivity of Gelb's labels disappears. On the model of the word "alphabet," which reflects the names of the first two Greek letters, alpha beta, I borrowed the term abjad from Arabic (it incorporates the first four Arabic letters; Daniels 1990). In parallel, I borrowed the term abugida from Ethiopic, where it likewise comes from the first four consonants and the first four vowels of the usual arrangement of the symbols. Abjad has gained some currency, but abugida is lagging behind "alphasyllabary," which was introduced by William Bright (1992) some two years after abugida was, perhaps because of his prominence in Dravidian linguistics circles (Bright 2000). I object to "alphasyllabary" because it gives the impression that the type is some sort of hybrid of alphabet and syllabary-whereas the point of the new typology is to establish not three, but five types of writing (Daniels 2009c, 1992).

When we look at the history of writing in these terms, we see immediately that no syllabary ever gave rise to a script of any other type. We see that on just one occasion an abjad gave rise to an alphabet (which then ramified all over Europe), and on two occasions, likely not independently, an abjad gave rise to abugidas (one of which ramified all over South and Southeast Asia).

There are two sources for syllabaries: independent invention, as we have seen, and abstraction from a logosyllabary. And there is one source for the abjad-a missing link left out of this list.

For logosyllabaries, let us look at the three ancient inventions of writing that we know to be independent. For the first one, thanks to the hardy writing material used, namely "tablets" of clay with characters impressed in them, we can actually observe the process. On the earliest ones, pictograms (that simply means little, stylized pictures; the term says nothing about what is represented by the icon) stand for morphemes - the content words of the Sumerian language, their sound and meaning at once. Over a fairly short time, the pictures had been abstracted into mere patterns impressed in the clay with the corner of a stylus, yielding the wedge-shaped marks that give the script its name of cuneiform.

In China, maybe 1500 years later, something very similar must have happened; but by the time of the earliest surviving Chinese texts, the Oracle Bone Inscriptions of about $1250 \mathrm{BCE}$, another step had been taken, and characters now are exhibiting a compound structure: there is a "semantic" component suggesting the meaning, and a "phonetic" component suggesting the sound. (Indeed 2000 years ago, when the characters were systematized and codified, the phonetic indications were quite exact.)

Finally, in the Yucatan peninsula of southeastern Mexico, by $900 \mathrm{CE}$ the Maya were using a full-fledged writing system. We cannot yet interpret any of the earlier symbol-systems found in Mexico, so we do not know whether any of the Maya's predecessors had full writing, though graphically they exerted notable influence. Its relation to its language is remarkably similar to the relation of cuneiform to Sumerian, and the origin of the characters is not unlike that of Chinese. 


\section{Writing in the World and Linguistics}

Why should these three languages, Sumerian, Chinese, and Mayan, have hosted the invention of writing, and not the languages of other urbanized culturessuch as those that spoke Indo-European, Semitic, or Quechuan languages?

Because in each of these languages, morphemes are basically monosyllabic.

People all over the world leave pictographs. Diringer (1968) has almost a dozen plates of them. For all we know, each of those pictographs stood for a specific word. But only with Sumerian, Chinese, and Mayan did pictographic logography turn into writing (where "writing" is defined as "A system of more or less permanent marks used to represent an utterance in such a way that it can be recovered more or less exactly without the intervention of the utterer"). Why only in these three cases (and probably Indus Valley, where the language is probably Dravidian (Parpola 2008))?

Because in these languages, morphemes are just a syllable long. Writing a picture representing a word's meaning also represents its sound-and it was soon, or eventually, realized that other words, whose meaning was not so easy to picture, with the same or similar sound, could also be represented by the picture. Thus Sumerian $t i$ means 'arrow', so a picture of an arrow could be used to represent the homophonous word $t i$ 'life'. In Chinese, $k$ ' $i u$ 'fur coat' could yield $k$ ' $i u$ 'to seek'.

And why is it syllabaries that appear when nonliterate people get the idea of writing from somewhere, and invent writing out of nothing? Because there is something basic about syllables in the brain: "segments" are acoustically a fiction; young children can segment words into syllables more readily than into phonemes; phonetic data in the mental lexicon are organized by syllable structure \& identity; adults illiterate in an alphabet are unable to manipulate phonemes.

So, if syllables are so ingrained, why did we ever move from syllabaries to abjads, alphabets, and abugidas?

My answer is: by accident (Daniels in press). By a chain of accidents. Note that I have not mentioned Egyptian, which is often claimed to be a fourth independent invention of writing. But if I am right about the relevance of syllabic morphemes in that process, then Egyptian is not a candidate, because Egyptian does not exhibit monosyllabicity - rather, its morphology is very like that of its relative Semitic. It has roots containing (usually) three consonants, and these roots are inflected by varying their vocalizations. A root may be one or two syllables and may be extended by a variety of derivational affixes, to which inflectional affixes are then added.

And since the lexical morphemes changed their shape with derivation and inflection, what remained constant in each sign was the consonants. This gave the Egyptians the idea that what is to be written is consonants (rather than syllables). Therefore, Egyptian hieroglyphs do not denote syllables, but only consonantsone, two, or three consonants per glyph, as well as some glyphs used only for their semantic value.

But if we ignore the surface differences - the pretty pictures versus the patterns of wedges; the denotation of consonants rather than syllables - then Egyptian and Sumerian writing work quite similarly. One sign denotes one morpheme, 
and because the vowels are not written, it denotes that morpheme no matter what its vocalization pattern. It is this property that suggests that the first would-be Egyptian scribe learned just a little bit of how Sumerian writing works-you use one pictogram per word - and got the idea to do the same with their own language. And they developed in the same way-with logograms, purely phonetic writing, phonetic complements, and semantic determinatives.

We have only recently discovered writing-like notations on so-called "tags" excavated at Abydos (Baines 2004). They resist interpretation in terms of later hieroglyphic writing, but could they not be seen as providing the graphic basis for a writing system in imitation of the Sumerian?

More than a thousand years later, a misunderstanding similar to the Sumerianto-Egyptian one resulted in the West Semitic abjad. Somehow, someone somewhere got the idea to limit each symbol to just one consonant-and less than 30 sufficed for their entire language. We used to think it was Semitic-speaking mine workers in the Sinai who left the first examples of this form of writing, but not long ago a pair of inscriptions was discovered at Wadi el-Hol, in Egypt proper, dating about the same time (Sass 1988; Hamilton 2006). They use what appears to be the same signary but cannot be interpreted as either Semitic or Egyptian. Thus who it was that invented the abjad, and what language it was first used for, remains up in the air.

Again a thousand years, again a misunderstanding, and the abjad turned into the alphabet at Greek hands, as well summarized in an excellent textbook:

All Phoenician letters stood for consonants, but some of these consonants did not exist in Greek. Thus, the letter ?alep stood for the glottal stop, which the Greeks did not have in their language. On the principle that the first sound of the letter's name was the sound of the letter, they apparently concluded that this particular letter stood for the vowel sound [a], and they called it alpha. By making the same mistake with several other consonant letters, they arrived somewhat by accident at a complete alphabet marking all the phonemes of their language." (Anderson 1989:387)

It was thus a chain of three mistakes that led to our most widespread type of writing system: Sumerian > Egyptian; Egyptian > West Semitic; Phoenician > Greek.

There are also various chains of faithful transmission of alphabets, abjads, and abugidas: Greek $>$ Etruscan $>$ Latin (Roman); Greek $>$ Coptic, Armenian, Georgian, Gothic, Cyrillic, Glagolitic; Aramaic $>$ Manichæan $>$ Sogdian $>$ Uyghur $>$ Mongolian $>$ Manchu; Aramaic $>$ Pehlevi $>$ Avestan; Brahmi throughout South and Southeast Asia; Arabic throughout Islamic civilization (Daniels 2000c). Sometimes improvements are made as they are used for new languages — often by the addition of new letters for new sounds (Daniels 2006a)-but sometimes scripts remain the same and it seems as though they couldn't possibly record their new languages, but they do.

And finally, there are instances of transmission of scripts to cultures that had grammatical traditions - and in each of these cases, there are improvements of the fit of the script to the new language: Aramaic > Kharoșthi; Aramaic and Kha- 


\section{Writing in the World and Linguistics}

roșthi > Brahmi; Brahmi > Tibetan; Tibetan via hPags pa $>$ Korean (Han'gŭl) (Daniels 2007).

(The best of them might be considered to be the Korean alphabet, where segmental letters are arranged into syllabic clusters - and the base shapes of the letters are taken to represent the shapes of the articulators used in making them, and the phonetically related sounds are denoted by additions to the base shapes.)

I conclude with a rather more complicated map (Figure 6) than the one I started with. We look not just at the shapes of the letters that spread across the globe, but at the ways the scripts represent their languages and the ways those ways were transmitted from culture to culture. The orange arrows represent the original three misunderstandings. The red arrows represent the gradual expansion and adaptation of scripts to new languages. The blue arrows hint at the use of basically the same script for many languages. The green arrows represent the deliberate alterations of scripts by grammarians. This is, I think, a more accurate picture of writing in linguistics and the world.

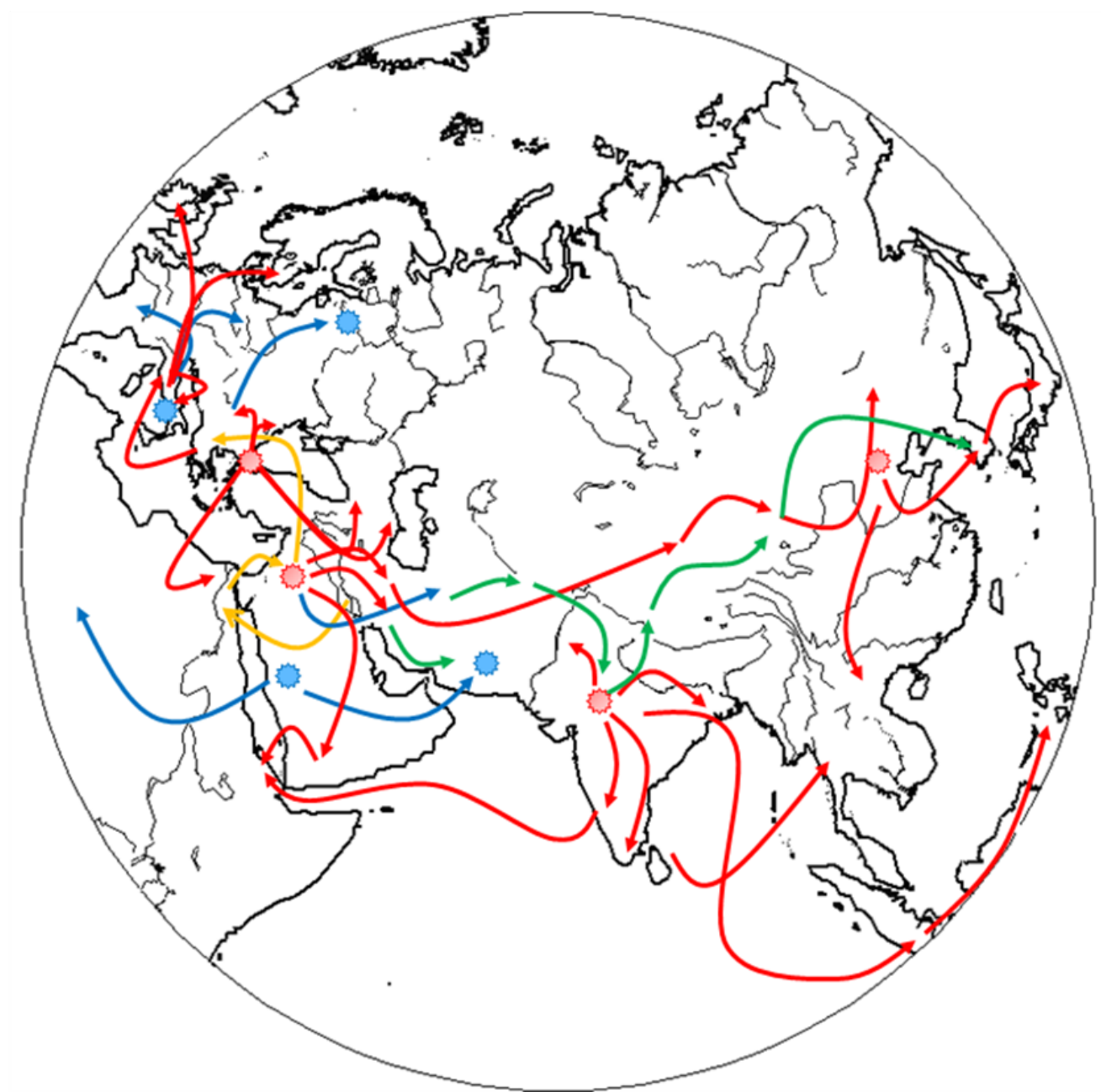

Figure 6. A representation of the "functional" history of writing 


\section{Peter T. Daniels}

\section{References}

Anderson, James M. 1989. Writing Systems. In William O'Grady, Michael Dobrovolsky, and Mark Aronoff eds., Contemporary Linguistics: An Introduction, 358-82. New York: St. Martin's.

Astle, Thomas. 1784. The Origin and Progress of Writing, as well Hieroglyphic as Elementary. London: Bensley.

Atkinson, B. F. C. 1930ff. Alphabet. In Encyclopcedia Britannica 14 ed., Vol. 1, pp. 677-85. Chicago: Encyclopædia Britannica.

Atkinson, B. F. C., and Joshua Whatmough. 1961?ff. Alphabet. In Encyclopadia Britannica, 14th ed., 1:662-69. Chicago: Encyclopædia Britannica.

Baines, John. 2004. The Earliest Egyptian Writing: Development, Context, Purpose. In Stephen D. Houston, ed., The First Writing: Script Invention as History and Process, 150-89. Cambridge: Cambridge University Press.

Black, Jeremy, ed. 2005. The Atlas of World History: Mapping the Human Journey, 2nd ed. New York: Dorling Kindersley.

Bloomfield, Leonard. 1914. An Introduction to the Study of Language. London: Bell.

Bloomfield, Leonard. 1933. Language. New York: Holt, Rinehart and Winston.

Bolinger, Dwight M. 1946. Visual Morphemes. Language 22:333-40.

Bowman, Elizabeth. 1966ff. Pictographs and Ideograms. Collier's Encyclopedia 19:30B-D, 31-35.

Bright, William. 2000. A Matter of Typology: Alphasyllabaries and Abugidas. Studies in the Linguistic Sciences (Urbana) 30:63-71.

Bright, William, ed. 1992. International Encyclopedia of Linguistics. New York: Oxford University Press.

Bundesdruckerei, Berlin. 1969. Alphabete und Schriftzeichen des Morgen- und des Abendlandes 2nd ed. Wiesbaden: Harrassowitz.

Caracteres et alphabets de langues mortes et vivantes. 1763. In D. Diderot, \& J. L. D'Alembert Eds., l'Encyclopédie; ou, Dictionnaire raisonné des sciences des arts et des métiers, vol. 19: Recueil de planches, sur les sciences, les arts libéraux, et les arts méchaniques, avec leur explications, sec. 2, part 1, pp. [150-91]. Paris. 


\section{Writing in the World and Linguistics}

Chao, Yuen-ren. 1940. A Note on an Early Logographic Theory of Chinese Writing. Harvard Journal of Asiatic Studies 5:189-91.

Christin, Anne-Marie, ed. 2002. A History of Writing: From Hieroglyph to Multimedia. Translated by Josephine Bacon, Deke Dusinbere, Ian McNorran, and David Stanton. Paris: Flammarion. French original, 2001.

Cohen, Marcel. 1958. La Grande Invention de l'écriture et son évolution. Paris: Imprimerie Nationale.

Coulmas, Florian. 1989. The Writing Systems of the World. Oxford: Blackwell.

Coulmas, Florian. 1996. The Blackwell Encyclopedia of Writing Systems. Oxford: Blackwell.

Coulmas, Florian. 2005. Writing Sytems: An Introduction to Their Linguistic Analysis. Cambridge: Cambridge University Press.

Daniels, Peter T. 1990. Fundamentals of Grammatology. Journal of the American Oriental Society 110:727-31.

Daniels, Peter T. 1991. Is a Structural Graphemics Possible? Eighteenth LACUS Forum (Ann Arbor) 528-37.

Daniels, Peter T. 1992. The Syllabic Origin of Writing and the Segmental Origin of the Alphabet. In Pamela Downing, Susan D. Lima, and Michael Noonan, eds., The Linguistics of Literacy, 83-110. Amsterdam \& Philadelphia: John Benjamins.

Daniels, Peter T. 2000a. Review of various popular books on writing. SinoPlatonic Papers.98:47-57. http://sino-platonic.org/complete/spp098_book reviews.pdf

Daniels, Peter T. 2000b. Syllables, Consonants, and Vowels in West Semitic Writing. Lingua Posnaniensis 42:43-55.

Daniels, Peter T. 2000c. On Writing Syllables: Three Episodes of Script Transfer. Studies in the Linguistic Sciences (Urbana) 30:73-86.

Daniels, Peter T. 2001. Writing Systems. In Mark Aronoff and Janie Rees-Miller, eds., The Handbook of Linguistics, 43-80. Malden, Mass.: Blackwell.

Daniels, Peter T. 2002. The Study of Writing in the Twentieth Century: Semitic Studies Interacting with Non-Semitic. Israel Oriental Studies 20:85-117. 
Peter T. Daniels

Daniels, Peter T. 2005. Language and Languages in the Eleventh Britannica. In Salikoko S. Mufwene, Elaine J. Francis, \& Rebecca S. Wheeler, eds., Polymorphous Linguistics: Jim McCawley's Legacy, 505-29. Cambridge: MIT Press.

Daniels, Peter T. 2006a. On Beyond Alphabets. Written Language and Literacy 9:7-24.

Daniels, Peter T. 2006b, September 8. Review of Writing Systems, by Florian Coulmas. Linguist List 17.2534. http://linguistlist.org/issues/17/17-2534.html

Daniels, Peter T. 2007. Littera ex occidente: Toward a Functional History of Writing. In Cynthia L. Miller, ed., Studies in Semitic and Afroasiatic Linguistics Presented to Gene B. Gragg (Studies in Ancient and Oriental Civilization, 60), 53-68. Chicago: Oriental Institute of the University of Chicago. http://oi.uchicago.edu/pdf/saoc60.pdf

Daniels, Peter T. 2009a. Grammatology. In David R. Olson and Nancy Torrance, eds., The Cambridge Handbook of Literacy, 25-45. Cambridge: Cambridge University Press.

Daniels, Peter T. 2009b. Peter Steven Duponceau and the Typology of Writing Systems. Paper presented at the annual meeting of the American Oriental Society, Albuquerque.

Daniels, Peter T. 2009c. Two Notes on Terminology. Written Language and Literacy 12:275-79.

Daniels, Peter T. in press. Three Models of Script Transfer. Word. Paper presented at the annual meeting of the International Linguistic Association, New York, 2004.

Daniels, Peter T., and William Bright, eds. 1996. The World's Writing Systems. New York: Oxford University Press.

de Jong, Cees W., Alston W. Purvis, and Jan Tholenaar, eds. 2009-10. Type: A Visual History of Typefaces and Graphic Styles. Cologne: Taschen.

DeFrancis, John. 1989. Visible Speech: The Diverse Oneness of Writing Systems. Honolulu: University of Hawaii Press.

Diringer, David. 1948. The Alphabet: A Key to the History of Mankind, 1st ed. New York: Philosophical Library. 
Writing in the World and Linguistics

Diringer, David. 1968. The Alphabet: A Key to the History of Mankind, 3rd ed., with the assistance of Reinhold Regensburger. 2 vols. New York: Funk \& Wagnalls.

Diringer, David. 1973ff. Alphabets. Encyclopcedia Britannica Macropcedia 15th ed.,. 1:618-27. Chicago: Encyclopædia Britannica.

Du Ponceau, Peter Stephen. 1838. Dissertation on the Nature and Character of the Chinese System of Writing ... Transactions of the Historical and Literary Committee of the American Philosophical Society, vol. 2.

Eco, Umberto. 1995. The Search for the Perfect Language. Trans. James Fentress. Oxford: Blackwell.

Fasold, Ralph, and Jeff Connor-Linton. 2006. An Introduction to Language and Linguistics. Cambridge: Cambridge University Press.

Faulmann, Carl. 1880a. Das Buch der Schrift enthaltend die Schriftzeichen und Alphabete aller Zeiten und aller Völker des Erdkreises, 2nd ed. Vienna: Verlag der Kaiserlich-Königlichen Hof- und Staatsdruckerei.

Faulmann, Karl. 1880b. Illustrierte Geschichte der Schrift. Vienna.

Février, James-Germain. 1959. Histoire de l'écriture 2nd ed. Paris: Payot.

Finegan, Edward, and Niko Besnier. 1989. Language: Its Structure and Use. San Diego: Harcourt Brace Jovanovich.

Fischer, Stephen Roger. 1999. A History of Language. London: Reaktion Books.

Fischer, Stephen Roger. 2001. A History of Writing. London: Reaktion Books.

Fischer, Stephen Roger. 2003. A History of Reading. London: Reaktion Books.

Fossey, Charles, ed. 1927. Notices sur les caractères étrangers, anciens et modernes. Paris: Imprimerie Nationale.

Friedrich, Johannes. 1966. Geschichte der Schrift unter besonderer Berücksichtigung ihrer geistigen Entwicklung. Heidelberg: Winter.

Fry, Edward. 1799. Pantographia; Containing accurate copies of all the known alphabets in the world; together with an English explanation of the peculiar force or power of each letter; to which are added, specimens of all wellauthenticated oral languages .... London: Cooper and Wilson.

Gair, James W. 1966ff. Alphabet. Collier's Encyclopedia 1:588-606. 


\section{Peter T. Daniels}

Gaur, Albertine. 1992. A History of Writing, 2nd ed. London: British Library.

Gaur, Albertine. 1994. A History of Calligraphy. London: British Library.

Gaur, Albertine. 2000. Literacy and the Politics of Writing. Bristol: Intellect Books.

Gelb, I. J. 1952. A Study of Writing. Chicago: University of Chicago Press.

Gelb, I. J. 1973ff. Writing, Forms of. Encyclopcedia Britannica Macropaedia, 15th ed., 19:1033-45. Chicago: Encyclopædia Britannica.

Giles, Peter. 1903. Writing. Encyclopcedia Britannica, 10th ed., 33:888-903. London.

Giles, Peter. 1910. Alphabet. Encyclopcedia Britannica, 11th ed., 1:723-32. Cambridge: Cambridge University Press.

[Giles, Peter.] 1911. Writing. Encyclopcedia Britannica, 11th ed., 28:852-53. Cambridge: Cambridge University Press.

Gleason, Henry Allan. 1961. An Introduction to Descriptive Linguistics, 2nd ed. New York: Holt, Rinehart and Winston.

Gnanadesikan, Amalia E. 2009. The Writing Revolution: Cuneiform to the Internet. Malden, Mass.: Wiley-Blackwell.

Günther, Hartmut, and Otto Ludwig, eds. 1994-96. Schrift und Schriftlichkeit: Ein interdisziplinäres Handbuch. Berlin \& New York: Walter de Gruyter.

Haarmann, Harald. 1990. Universalgeschichte der Schrift. Franfurt: Campus Verlag.

Haarmann, Harald. 1994. Entstehung und Verbreitung von Alphabetschriften. In Hartmut Günther and Otto Ludwig, eds., Schrift und Schriftlichkeit: Ein interdisziplinäres Handbuch internationaler Forschung, 1:329-47. Berlin \& New York: Walter de Gruyter.

Hall, Robert A., Jr. 1960. A Theory of Graphemics. Acta Linguistica Hafniensia 8:13-20.

Hall, Robert A., Jr. 1963. Graphemics and Linguistics. In Viola E. Garfield and Wallace L. Chafe, eds., Symposium on Language and Culture: Proceedings of the 1962 Annual Spring Meeting of the American Ethnological Society, 53-59. Seattle: American Ethnological Society. 
Hall, Robert A., Jr. 1964. Introductory Linguistics. Philadelphia: Chilton Books.

Hamilton, Gordon J. 2006. The Origins of the West Semitic Alphabet in Egyptian Scripts. Washington, D.C.: Catholic Biblical Association of America.

Haywood, John. 2009. Atlas of World History: From the Ancient World to the Present. New York: Fall River.

Hensel, Gottfried. 1741. Synopsis universae philologiae, in qua miranda unitas et harmonia linguarum totius orbis terrarum occulta, e literarum, syllabarum, vocumque natura \& recessibus, eruitur. Nuremberg.

Herrick, Earl M. 1974. A Taxonomy of Alphabets and Scripts. Visible Language $8: 5-32$.

Hill, Archibald A. 1967. The Typology of Writing Systems. In William M. Austin, ed., Papers in Linguistics in Honor of Léon Dostert, 93-99. (Janua Linguarum Series Maior, 25.) The Hague: Mouton.

Hockett, Charles F. 1958. A Course in Modern Linguistics. N.p.: Macmillan.

Jean, Georges. 1992. Writing: The Story of Alphabets and Scripts. New York: Abrams.

Jensen, Hans. 1969. Sign, Symbol and Script: An Account of Man's Efforts to Write. Trans. George Unwin. London: George Allen \& Unwin.

Johnson, John. 1824. Typographia. London: Author.

Kopp, Ulrich Friedrich. 1819-21. Bilder und Schriften der Vorzeit. Mannheim: Author.

Kulundžić, Zvonimir. 1957. Knjiga o knjizi. Zagreb.

Losty, Jeremiah P. 1982. The Art of the Book in India. London: British Library.

Malkiel, Yakov. 1968. Secondary Uses of Letters in Language. In Essays on Linguistic Themes, 357-98. Berkeley \& Los Angeles: University of California Press.

Man, John. 2000. Alpha Beta: How Our Alphabet Shaped the World. London: Headline.

Mittelberger, Hermann. 1973ff. Ancient Epigraphic Remains. Encyclopcedia Britannica Macropadia 15th ed. 1:837-39. Chicago: Encyclopædia Britannica. 
Nakanishi, Akira. 1980. Writing Systems of the World: Alphabets Syllabaries Pictograms. Rutland, Vt.: Tuttle.

Nash, Ray, R. Barbour, T. J. Brown, R. H. Pinder-Wilson, D. M. Anderson, C. Yee, et al. 1973ff. Calligraphy. Encyclopoedia Britannica Macropcedia 15th ed., Vol. 3, pp. 645-70. Chicago: Encyclopædia Britannica.

Ostler, Nicholas. 2005. Empires of the Word. London: HarperCollins.

Parpola, Asko. 2008. Is the Indus Script Indeed Not a Writing System? In Airāvati: Felicitation Volume in Honour of Iravasham Mahadevan, 111-31. Chennai: varalaaru.com.

Peters, Arno. 1990. Peters Atlas of the World. New York: Harper and Row. German original, 1989.

Puhvel, Jaan. 1973ff. Epigraphy. Encyclopcedia Britannica Macropcedia 15th ed., 6:915-25. Chicago: Encyclopædia Britannica.

Radford, Andrew, Martin Atkinson, David Britain, Harald Clahsen, and Andrew Spencer. 2009. Linguistics: An Introduction. Cambridge: Cambridge University Press.

Robins, Robert H. 1987. Duponceau and Early Nineteenth Century Linguistics. In Hans Aarsleff, Louis G. Kelly, and Hans-Josef Niederehe, eds., Papers in the History of Linguistics: Proceedings of the Third International Conference on the History of the Language Sciences ICHoLS III, Princeton, 19-23 August 1984, 435-46. Amsterdam \& Philadelphia: John Benjamins.

Robinson, Andrew. 1995. The Story of Writing: Alphabets, Hieroglyphs and Pictograms. London: Thames and Hudson.

Robinson, Andrew. 2002a. Lost Languages: The Enigma of the World's Undeciphered Scripts. New York: McGraw Hill.

Robinson, Andrew. 2002b. The Man Who Deciphered Linear B: The Story of Michael Ventris. London: Thames \& Hudson.

Robinson, Andrew. 2006. The Last Man Who Knew Everything: Thomas Young, the Anonymous Genius Who Proved Newton Wrong and Deciphered the Rosetta Stone, among Other Surprising Feats. London: Pi Press.

Robinson, Andrew. 2009. Writing and Script: A Very Short Introduction. Oxford: Oxford University Press. 


\section{Writing in the World and Linguistics}

Rogers, Henry. 2005. Writing Systems: A Linguistic Approach. Malden, Mass.: Blackwell.

Sacks, David. 2003. Language Visible. New York: Broadway Books.

Sampson, Geoffrey. 1985. Writing Systems. London: Hutchinson.

Sass, Benjamin. 1988. The Genesis of the Alphabet and Its Development in the Second Millennium B.C. Wiesbaden: Harrassowitz.

Saussure, Ferdinand de. 1959. Course in General Linguistics. Charles Bally, Albert Sechehaye, and Albert Riedlinger, eds., and Wade Baskin, trans. New York: Philosophical Library.

Saussure, Ferdinand de. 1983. Course in General Linguistics. Charles Bally, Albert Sechehaye, and Albert Riedlinger, eds., and Roy Harris, trans. LaSalle, Ill.: Open Court.

Schele de Vere, Maximilian. 1853. Outlines of Comparative Phonology, with a sketch of the languages of Europe, arranged upon philologic principles; and a Brief History of the Art of Writing. New York: Putnam.

Schmidt, Alfred. 1980. Entstehung und Entwicklung von Schriften. Claus Haebler, ed. Cologne: Böhlau.

Smith, Murphy D. 1983. Peter Stephen Du Ponceau and His Study of Languages. Proceedings of the American Philosophical Society 127:143-79.

Taylor, Isaac. 1899. The Alphabet, 2nd ed. London: Edward Arnold.

Urry, William G. 1973ff. Paleography. Encyclopcedia Britannica Macropaedia 15th ed., 13:911-14. Chicago: Encyclopædia Britannica.

Voegelin, Charles F., Florence M. Voegelin. 1961. Typological Classification of Systems with Included, Excluded and Self-Sufficient Alphabets. Anthropological Linguistics 3(1):55-96.

Peter T. Daniels 254 Palisade Ave. Jersey City, NJ 07307

grammatim@verizon.net 